\title{
The Role of MSME Growth as a Mediation Variable in Financial Inclusion: Evidence from Indonesia
}

\author{
Endang Tri Widyarti, Idris Idris, Irene Rini Demi Pangestuti, Hersugondo Hersugondo* \\ Faculty of Economic and Business, Diponegoro University, Semarang, 50275, Jawa Tengah, Indonesia
}

Received August 13, 2021; Revised October 15, 2021; Accepted November 11, 2021

\section{Cite This Paper in the following Citation Styles}

(a): [1] Endang Tri Widyarti, Idris Idris, Irene Rini Demi Pangestuti, Hersugondo Hersugondo , "The Role of MSME Growth as a Mediation Variable in Financial Inclusion: Evidence from Indonesia," Universal Journal of Accounting and Finance, Vol. 9, No. 6, pp. 1387-1393, 2021. DOI: 10.13189/ujaf.2021.090617.

(b): Endang Tri Widyarti, Idris Idris, Irene Rini Demi Pangestuti, Hersugondo Hersugondo (2021). The Role of MSME Growth as a Mediation Variable in Financial Inclusion: Evidence from Indonesia. Universal Journal of Accounting and Finance, 9(6), 1387-1393. DOI: 10.13189/ujaf.2021.090617.

Copyright $\bigcirc 2021$ by authors, all rights reserved. Authors agree that this article remains permanently open access under the terms of the Creative Commons Attribution License 4.0 International License

\begin{abstract}
Financial inclusion as the goal of the countries in the world has been considered important by international policymakers even though every country has its specific development models. The MSME sector can encourage economic growth and create jobs so that the MSME sector can stabilize the economy. The development of MSMEs in Indonesia also shows growth every year. Based on these data, the government must continue to increase the growth of MSMEs, because, with the increase of MSMEs, the number of workers will also increase. This research is quantitative, meaningful research that describes conditions of financial inclusion in Central Java and Indonesia. The data in this study used secondary data. Secondary data obtained were from supporting data through literature studies, journals, mass media articles, and books related to this research topic. The purposes of this study are to map the growth of MSME's Supporting Model in Financial Inclusion and determine the level of financial inclusion in the regional scale of Central Java by developing a model at the level of financial inclusion in Indonesia for a national scale.
\end{abstract}

Keywords Mediating Role, Financial Inclusion, MSME's Growth

\section{Introduction}

Financial inclusion as the goal of a country has been acknowledged as fundamental by international policymakers even though every country has its specific development models. One of the essential focuses of the financial inclusion-related issue is the condition of small and medium enterprises (MSMEs) and the quality of financial services for the poor. MSMEs' accessibility to financing services from banks is imperative considering their contribution to reducing unemployment and poverty rates in developing countries.

In Indonesia, the cause of the MSMEs financing services-related problems is the unclear separation between companies and family members [13]. Their involvement in the production process overlaps their role either as producers or consumers of goods and services [8]. Responding to the problems, the government implements financial inclusion to assist MSMEs businesses in accessing capital, under BI Regulation No.17 / 12 / PBI / 2015, stated that commercial banks to reach the MSMEs credit ratio of the total loans disbursed at least 20 percent.

According to Ross Brown (2019), MSMEs with high growth tend to seek external funding such as bank loans, while the ease of accessing financial credit, supported by legislation from European governments, significantly encourages the MSMEs growth (Moreira 2016). Antonia Grohmann a, Theres Klühs b (2018) stated that an increase in financial literacy in a diverse population influences the gross domestic product (GDP) per capita, as GDP is one measurement of financial inclusion. In addition, according to Maciej Woźniaka, et.al, (2019), medium enterprises' growth affects financial inclusion, while micro and small enterprises do not affect financial inclusion in Poland. 
The growth of MSME in Indonesia can be seen from the following table 1.

Table 1. Growth of MSME's in Indonesia

\begin{tabular}{|c|c|c|c|}
\hline Year & $\begin{array}{c}\text { Number of } \\
\text { MSME's }\end{array}$ & $\begin{array}{c}\text { Growth of } \\
\text { MSME's } \\
\text { (\%) }\end{array}$ & $\begin{array}{c}\text { Number of } \\
\text { MSME's workers }\end{array}$ \\
\hline 2010 & 52.764 .750 & 2,01 & 96.193 .623 \\
\hline 2011 & 54.114 .821 & 2,57 & 98.238 .913 \\
\hline 2012 & 55.206 .444 & 2,41 & 101.722 .458 \\
\hline 2013 & 56.534 .592 & 2,41 & 107.657 .509 \\
\hline 2014 & 57.895 .721 & 2,36 & 114.144 .082 \\
\hline 2015 & 59.262 .772 & 3,87 & 123.229 .386 \\
\hline 2016 & 61.651 .177 & 2,06 & 112.828 .610 \\
\hline 2017 & 62.922 .617 & 2,02 & 116.673 .416 \\
\hline
\end{tabular}

Source: (The Indonesian Ministry of Cooperatives and Small and Medium Enterprises).

Many researchers have carried out studies related to MSME financing in encouraging national economy and Financial Inclusion. For example, Nengsih (2015) and Mohieldin M, et al,. (2012) argued that Islamic Banking has high potential in implementing Financial Inclusion as proven by an increase in third-party funds (DPK) and an increase in microfinance. Rifa'i.A (2017) examined the role of the Sharia People Financing Bank in implementing financial inclusion through MSME Financing. Mohiuddin, et al., (2018) investigated the judgment taken by large companies in Pakistan to be reluctant to adopt business in
Islamic banking but more inclined to choose conventional banks. Allen, et. al, (2016), in The Foundations of Financial Inclusion: Understanding Ownership and Use of Formal Accounts, explored factors driving a country's financial inclusion to be stronger.

According to Cheng (2010), in the revised National Literacy Strategy Inclusive Financial (SNLKI), public financial literacy will be followed by public financial inclusion, while the World Bank Global FINDEX [12] reported that the National Financial Inclusion index in Indonesia was $19.6 \%$ in 2011. In 2016, Indonesia's financial inclusion rate was able to reach $67.82 \%$, but the increase was not in line with the increase in financial literacy as analyzed by OJK [5]. This might be due to the lack of awareness in managing funds, affordability of bank administration fees, trust in financial institutions, lack of documentation or records of business, religious or cultural activities of the community, consumer experience in using bank services [17].

The results of a survey by Fintec News Singapore (2018) showed that more and more people have been using fintech services to do transactions and loan services, which expands to reach financial inclusion in Indonesia. A high increase in GDP per capita can be obtained with the use of high financial services as well (Antonia Grohmann a, Theres Klühs b, 2018). According to the PPN/BAPPENAS in 2018, Fintech was a form of the implementation of the National Financial Inclusive Strategy (SNKI).

\section{Literature Review}

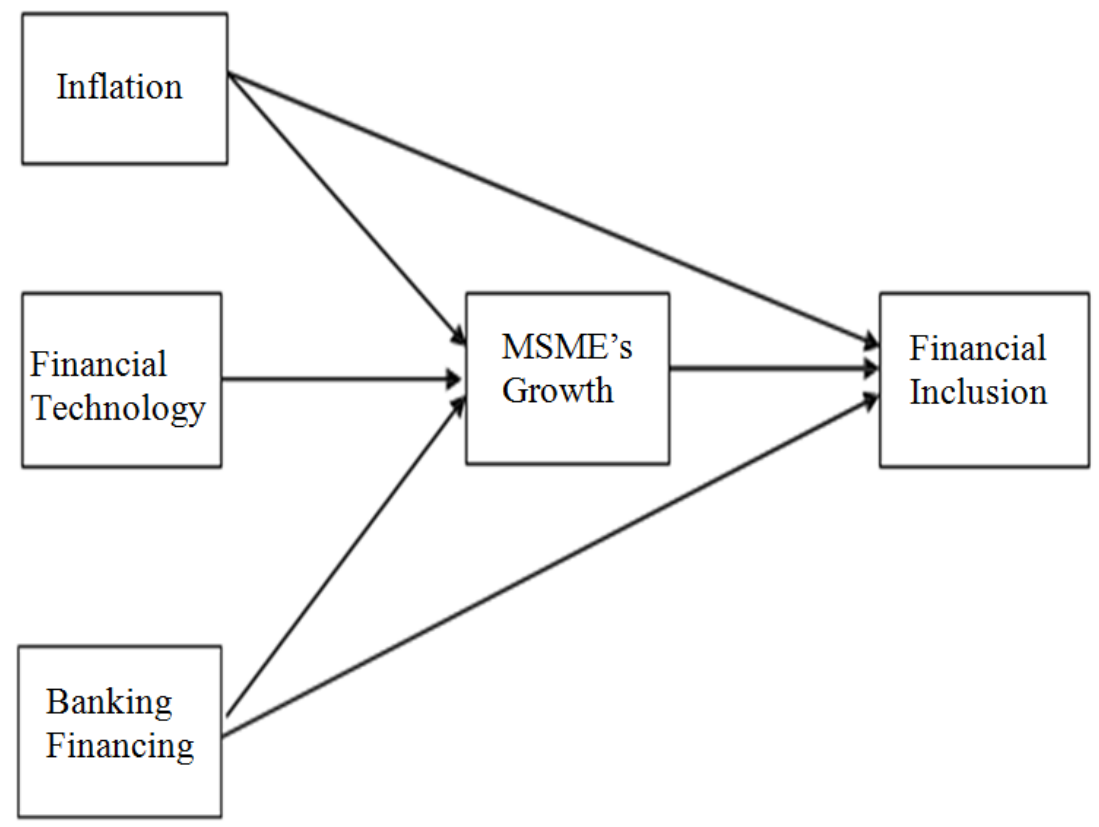

Figure 2. Theoretical Framework 


\subsection{Inflation}

Theoretically, inflation is a condition in which the prices of goods, services, and production factors increase [11]. This definition indicated a weakening of purchasing power followed by a decline in the real (intrinsic) currency value of a country [13]. According to Martin Feldkircher (2019), inflation is driven by two determinants sets; local or domestic factors versus international or global forces. The local determinants include the changes of technical progress, productivity, and demographics, such as institutional considerations on the inflation target, central bank independence, and systemic adoption of monetary policy in the economy. However, in general, economists tend to differentiate aggregate demand and changes in sources of inflationary pressure.

Other surveyed or experimented to measure respondents regarding the level of financial and economic literacy as well as their expectations or the level of perceived inflation. Since "understanding inflation" is only one of the four elements of the definition of financial literacy, the study has not focused only on people's understanding of inflation but its causes and consequences. (Binder and Rodrigue in Fabio Rumler, 2019).

\subsection{Financial Technology}

Bank Indonesia (2015) classified financial technology into four categories, as follows:

\subsubsection{Crowdfunding and peer-to-peer (P2P) lending}

The basis of the classification is the function of the platform of a meeting place between capital seekers and investors concerning loans. Technology information-based platforms, especially the internet, have been used to provide loan services.

\subsubsection{Market aggregator}

This category is a media collecting financial data from various data providers for the users' benefit.

\subsubsection{Risk and investment management}

The following categories are classifications for financial technology services that function as financial planners in digital form.

\subsection{Bank Financing}

According to Al Arif in Fajar Mujaddid (2018), financing is funding provided by one party to another to support the planned investment of either individual or institution. According to Law No. 10 of 1998 concerning banking, financing is the provision of money or bills based on an agreement between a bank and other parties, which requires the financed party to return the money or the bills after a certain period in return.

\subsection{Growth of MSME's}

There has been substantial literature investigating factors impeding the performance of MSMEs, including lack of credit access and adoption of less effective business practices. For example, according to Long Quang Trinha (2018), micro, small, and medium-sized enterprises (MSMEs) play an important role in job creation, industrial development, and economic advancement. Yet, studies of the underlying drivers of MSME growth are rare, especially for developing countries. In their study of small firms in India, Coad, A., \& Tamvada (2012) found that exporting firms show faster growth than non-exporting firms. However, such studies were limited, and further research on the influence of internationalization activities on firm growth in developing countries was thus warranted.

\subsection{Financial Inclusion}

Andrian Thomas (2013) defined financial inclusion as all efforts aimed at eliminating all forms of price and non-price barriers to public access to financial services. Goodell (2020) defined financial inclusion as the availability of access to various financial institutions, products, and services following the needs and abilities of the community to improve public welfare.

Gavriilidis, et al, (2016) developed questionnaires that could be used to measure the level of financial inclusion. The measurement of financial inclusion is as follows

\subsubsection{Product holding}

Four indicators characterizing financial products are savings or pension products, payment products, current accounts, or e-money (not including credit cards), insurance, and credit or mortgage products.

\subsubsection{Product awareness}

The awareness of the products will prevent choice erroneousness and help financial products providers identify the demands of the public.

\subsubsection{Product choice}

When monitored properly, financial inclusion is very beneficial for consumers; for example, holding insurance that does not meet their needs, credit products that charge because of high interest rates or using unnecessary transaction services with expensive payment facilities.

\subsubsection{Seeking alternatives to formal financial services}

The last indicator is used to identify people who are potential without access to formal financial services. The question draws on two things, which are whether people turn to family or friends for financial support. The results reflect some factors, including the extent to which people are actively saving in whatever way and how far they meet their needs. However, it also shows that there may 
be room for designing simple and inexpensive products to meet consumer needs.

\section{Research Methods}

\subsection{Type of Writing and Research Approach}

This quantitative research was intended to describe conditions of financial inclusion in Central Java and Indonesia. The data were analyzed using descriptive statistical testing and bias non-response testing supported by SPSS version 20. This study, entitled the effect of variables Growth of MSMEs, Theory of Intermediary Financial, Financial Inclusion on Mapping Growth in the regional scale of Scale Java, consisted of Growth of MSMEs, Theory of Intermediary Financial, Financial Inclusion to Developing model the level of financial inclusion in Indonesia for national scale.

\subsection{Types of Data and Data Collection Methods}

The secondary data collected from Bloomberg were literature studies, journals, mass media articles, and book-related research topics. The method used was a non-probability sampling technique with a convenience sampling method. The sample was 360 having complete monthly data from 2013 to 2018. According to Liu (2020), a sample of 100-200 may represent the population, and Roscoe (1975) in Ferneini (2020) stated that samples, which are greater than 30 and less than 500 are sufficient for general research.

The data collection method used in this writing followed such methods:

\subsubsection{Observation}

Observation is activity towards a series of processes or objects to feel and understand the knowledge of a phenomenon/event based on previously known information and ideas, to obtain the information needed to continue research by developing a model of the level of financial inclusion in Indonesia for national scale [25].

\subsubsection{Literature Study}

Literature studies were carried out by reading the scientific literature related to and supporting this writing through credible sources, in the form of printed and electronic libraries (internet data) with Growth of MSMEs Supporting Model in Financial Inclusion in the regional scale of Central Java (Viverita, et. al, 2015).

- Growth of MSME's

- Theory of Intermediary Financial

- Financial Inclusion

\subsubsection{Documentary}

Documentation studies were conducted by examining related reports and internet accessible articles, credible books, and journals supporting the research problems. In this method, the authors only included relevant data from a source or documents required in the study of Mapping Growth of MSMEs Supporting Model in Financial Inclusion and determine the level of financial inclusion in the regional scale of Central Java (Mohiuddin, et. al, 2018).

\subsection{Data Analysis Method}

The data processing and hypothesis testing were conducted using Warp PLS application program version 5.0. SEM is path analysis, so it is possible to test and estimate the relationship between exogenous and endogenous multiple variables with many indicators simultaneously (Ghozali, Imam, 2011). The Warp PLS version 5.0 has its flexibility and various advantages of Regression in PLS.

\section{Results}

\subsection{Underlying Models with Mediation Variables after Change}

According to Shahulhameedu (2014), after altering the underlying model, variables affecting the achievement of SMEs are intervened by the variable of monetary consideration. By entering several basic markers, the arrangement is as shown in Table 1. The aftereffect of the underlying model testing showed that the lists met the measures for over fitting. The CMIN/ DF $=1.625<2$, the CFI model of 0.924 was $\geq 0.90$, and the RMSEA $=$ $0.079 \leq 0.08$. This standard indicated that the model was shaped as per the information. Besides, the GFI $=0.739$, AGFI $=0.624$, and the NFI $=0.830$ for the reasonableness of the model including the medium classification [13].

Table 1. Integrity of fit file underlying model with intercession factors after adjustment

\begin{tabular}{|c|c|c|c|}
\hline $\begin{array}{c}\text { Goodness of fit } \\
\text { statistics }\end{array}$ & $\begin{array}{c}\text { Cut of } \\
\text { value }\end{array}$ & $\begin{array}{c}\text { Model } \\
\text { results }\end{array}$ & Criteria \\
\hline CMIN/DF & $<2.0$ & 1.625 & Good \\
\hline GFI & $\geq 0.90$ & 0.739 & Moderate \\
\hline RMSEA & $\leq 0.08$ & 0.079 & Good \\
\hline CFI & $\geq 0.90$ & 0.924 & Good \\
\hline AGFI & $\geq 0.90$ & 0.624 & Moderate \\
\hline NFI & $\geq 0.90$ & 0.830 & Moderate \\
\hline TLI & $\geq 0.90$ & 0.896 & Moderate \\
\hline
\end{tabular}

Source: Processed Data, 2021

For the steady fit standards, the model had decent reasonableness shown by the value of NNFI/TLI $=0.896$, which was practically near the value of cut-off significant worth 0.90. Saleh (2016) explained that from the file of 
decency of fit, it tends to be seen that the proposed model is acceptable because the model can clarify the genuine information about the example of connections between investigates builds.

\subsection{Results of Data Processing}

The aftereffect of information preparing with changed model acquired outcome is as follows Table 2.

[30] The interior elements influencing business achievement had a value of C.R $=-2.653$ and $\mathrm{P}<0.05$, while the outer elements of SMEs influencing business accomplishment had a value of C.R $=2.708$ and $\mathrm{P}<0.05$. The SME interior factors affecting monetary incorporation had a $C . R=-3.533$ and $\mathrm{P}<0.05$, while the outside factors influencing the monetary consideration had a C.R $=2.961$ and $\mathrm{P}<0.05$. The C.R variable value of the monetary of the SME was 4.088 and $\mathrm{P}<0.05$, so the announced monetary incorporation has an impact on business achievement. The aftereffect of the causality test showed that the basic proportion of the value (C.R) was not equivalent to zero (all $>2$ ), and $P<0.05$, so it tended to be expressed that there was a genuine connection between interior factors, outside factors, and monetary incorporation to business achievement [31].

Table 3 shows that the immediate impact of the inside factors on business achievement factors was -0.773 [32]. The aberrant effect of the inside factors on the business accomplishment through monetary incorporation was generated from $(\beta 1 \times \beta 7)$. i.e., -0.204 . So, the impact of the absolute inner variables on business achievement was $(-0.773+-0.204)=-0.977$. The immediate effect of the outside factors on business achievement was 2.949, the roundabout impact of the outer variables on business achievement through monetary incorporation acquired from $(\beta 2 \times \beta 7)$ was 0.944 .

So, the impact of the absolute outer elements on business achievement was $(2.949+0.944)=3.893$. As the immediate effect of the inward factors on monetary consideration was -0.083 . [33], and no complicated impact between the factors, the absolute effect remained at -0.083 . The direct impact of the outside factors on monetary incorporation was 0.383 , the all-out impact was 0.383. The immediate impact of the monetary consideration on business achievement was 2.464, and no circuitous impact between the factors, so the absolute impact remained at 2.464 [34].

The achievement of SMEs, such as jewel stone craftsmen in Magelang District, Indonesia, was affected by different elements, both interior elements, and outside factors. The inside factor measurement used to dissect the impact of SMEs achievement of stone experts comprises of HR perspective, monetary viewpoint, specialized angle, creation and functional, and market and showcasing perspective. [35] The outside factors utilized to investigate the impact of the achievement of SMEs comprises Parts of government strategy, socio-social and financial viewpoints, and the job of related foundations. [36] Interior elements can influence the achievement of SMEs straightforwardly or then again in a roundabout way. The aberrant impact will be interceded by the monetary incorporation variable of SME entertainers comprising of accessibility/access to monetary administrations, the utilization of monetary items and administrations, nature of monetary items and administrations, and the government assistance of clients of monetary items and administrations. [37] The achievement of SMEs is estimated by a few markers as follows: Deals development, capital development, business development, market development, and benefit development.

Table 2. Assessment of relapse weight full model boundaries

\begin{tabular}{|c|c|c|c|c|c|}
\hline Endogenous variables $\rightarrow$ exogenous variables & Estimate & S.E & C.R & P & Remarks \\
\hline Internal factors $\rightarrow$ business success & 0.773 & 0.219 & 3.533 & 0.000 & Significant \\
\hline External factors $\rightarrow$ business success & 2.949 & 0.996 & 2.961 & 0.003 & Significant \\
\hline Internal factors $\rightarrow$ financial inclusion & 0.083 & 0.031 & 2.653 & 0.008 & Significant \\
\hline External factors $\rightarrow$ financial inclusion & 0.383 & 0.142 & 2.708 & 0.007 & Significant \\
\hline Financial inclusion $\rightarrow$ business success & 2.464 & 0.603 & 4.088 & 0.000 & Significant \\
\hline
\end{tabular}

Source : Personal Processed Data, 2021

Table 3. Coefficients worth of immediate, aberrant and aggregate connections among exogenous and endogenous factors

\begin{tabular}{|c|c|c|c|}
\hline Variables & Total effect & Indirect effect & Direct effect \\
\hline Internal factors $\rightarrow$ business success & 0.977 & 0.204 & 0.773 \\
\hline External factors $\rightarrow$ business success & 3.893 & 0.944 & 2.949 \\
\hline Internal factors $\rightarrow$ financial inclusion & 0.083 & 0.000 & 0.083 \\
\hline External factors $\rightarrow$ financial inclusion & 0.383 & 0.000 & 0.383 \\
\hline Financial inclusion $\rightarrow$ business success & 2.464 & 0.000 & 2.464 \\
\hline
\end{tabular}

Source : Private Processed Data, 2021 


\section{Conclusions}

This investigation examines the phenomenon of grouping strategy in Indonesia and the effect of data discrepancy on grouping conduct. The first approach utilizes the $\mathrm{CH}$ strategy for estimating scattering return, while the subsequent methodology employs CCK. The difference between $\mathrm{CH}$ and $\mathrm{CCK}$ techniques is that $\mathrm{CH}$ uses standard deviation, while CCK utilizes the total deviation of individual returns.

The study focuses on the relationship between crowding conduct and economic situations; however, the effect of data lopsidedness on grouping conduct is exceptionally restricted. Hwang and Salmon state that the power of grouping by institutional financial backers happens when the market is steadier. This outcome is supported by those who found the marvel of grouping conduct in Indonesia that not just occurs in outrageous fluctuating economic situations, yet when the market is in a steady condition.

Consequences of our examination tracked down that over the low degree of cost changes, as cost increments, financial backers are bound to follow the groups, yet, when the cost fluctuates generally, there is no wonder of grouping conduct distinguished in IDX in 2008. Non-negative relationship on quadratic capacities shows that there is no crowding wonder. Nonetheless, this investigation discovered that data imbalance reinforces the probability of grouping conduct. The higher the data unevenness between educated merchants and ignorant dealers pushed return scattering lower. This investigation suggests that data unevenness is an important condition for the presence of grouping conduct.

Our examination can be utilized to enhance the examination of crowding conduct in Indonesia. Specifically, future examinations need to test the level of data lopsidedness in Indonesia capital market when the economic situation is steady what's more, fluctuative to explore whether the wonder of crowding conduct is influenced by economic situations or data unevenness.

The shortcoming of this investigation is inspecting the wonder of crowding conduct in 2021 without dividing between a period of market pressure and ordinary condition. Further examination is proposed to incorporate economic situations and level of data deviation to give a more delegated result.

\section{Acknowledgments}

This article is the research output with an international publication research scheme with non-state budget funding sources at Diponegoro University for the 2021 fiscal year.

\section{REFERENCES}

[1] N. L. Ross Brown, "Strapped for Cash ? Funding for UK High Growth SMEs Since The Global Financial Crisis,” J. Bus. Res., vol. 99, pp. 37-45, 2019.

[2] D. F. Moreira, "The Microeconomic Impact on Growth of SMEs When The Access to Finance Widens: Evidence from Internet and High-Tech Industry," Procedia - Soc. Behav. Sci., vol. 220, pp. 278-287, 2016.

[3] L. M. Antonia Grohmann, Theres Klühs, "Does financial literacy improve financial inclusion? Cross country evidence,” J. World Dev., vol. 111, pp. 84-96, 2018.

[4] T. B. Maciej Woźniaka, Joanna Dudaa, Aleksandra Gąsiorb, "Relations of GDP Growth and Development of SMEs in Poland,” Procedia Comput. Sci., vol. 159, pp. 2470-2480, 2019.

[5] Badan Pusat Statistik, "Jumlah dan Perkembangan UMKM di Indonesia,” BPS RI, vol. 1, no. 4, p. 12, 2016.

[6] N. Nengsih, "Peran Perbankan Syariah Dalam Mengimplementasikan Keuangan Inklusif Di Indonesia,” Etikonomi, vol. 14, no. 2, pp. 1-32, 2015.

[7] F. X. Mohieldin M, Iqbal Z, Rostom A, "The Role of Islamic Finance in Enhancing Financial Inclusion in Organization of Islamic Cooperation ( OIC ) Countries,” Islam. Financ., vol. 20, no. 2, pp. 55-120, 2012.

[8] R. .A, "Peran Bank Pembiayaan Rakyat Syariah Dalam Mengimplementasikan Keuangan Inklusif Melalui Pembiayaan UMKM,” UMKM, vol. 2, no. 2, pp. 177-200, 2017.

[9] F. Z. R. Mohiuddin, Zaeema Asrar, Rukhshinda Begum, "Ineffective Awareness of Islamic Banking Products as A Root Cause of Reluctance for the Same by Corporate Customers: A Case Study of MCB - NIB Merger in Pakistan,” Eur. Sci. Journal, ESJ, vol. 14, no. 13, p. 134, 2018.

[10] M. S. M. P. Allen, Franklin, Asli Demirguc-Kunt, Leora Klapper, "The Foundations of Financial Inclusion: Understanding Ownership and Use of Formal Accounts," J. Financ. Intermediation, vol. 27, pp. 1-30, 2016.

[11] X. and H. D. Cheng, "The Impact of Bank and Non-Bank Financial Institutions on Local Economic Growth in China," J. Financ. Serv. Res., vol. 37, no. 2-3, pp. 179-99, 2010.

[12] K. PPN/BAPPENAS, Kondisi Pertumbuhan Ekonomi. 2018.

[13] R. Rinofah, "Pengaruh Variabel Ekonomi Makro Terhadap Penyaluran Kredit Umum dan UMKM di Daerah Istimewa Yogyakarta," UMKM, vol. 1, no. 1, 2015.

[14] P. L. S. Martin Feldkircher, "Global Inflation Dynamics and Inflation Expectations,” J. Int. Rev. Econ. Financ., vol. 64, pp. 217-241, 2019.

[15] M. T. V. Fabio Rumler, "Inflation literacy and inflation expectations: Evidence from Austrian household survey data,” J. Econ. Model., 2019.

[16] Bank Indonesia, Profil Bisnis Usaha Mikro, Kecil Dan Menengah (Umkm) Kerjasama Lppi Dengan Bank Indonesia Tahun 2015. 2015. 
[17] G. F. S. Fajar Mujaddid, "Pengaruh Pembiayaan UMKM dan Rasio Keuangan Terhadap Pertumbuhan Laba Bank Umum Syariah di Indonesia,” J. Ekon. Islam, vol. 9, no. 2, 2018.

[18] H. T. T. D. Long Quang Trinha, "Internationalization and The Growth of Vietnamese Micro, Small, and Medium Sized Enterprises: Evidence from Panel Quantile Regressions,” J. Asian Econ., vol. 55, pp. 71-83, 2018.

[19] J. P. Coad, A., \& Tamvada, "Firm growth and barriers to growth among small firms in India,” Small Bus. Econ., vol. 93, no. 2, pp. 838-400, 2012.

[20] Andrian Thomas, "Analisis Dampak Target The Fed Rate Terhadap Kebijakan Moneter Bank Indonesia,” Moneter, vol. 2, no. 1, p. 13, 2013.

[21] J. W. Goodell, "COVID-19 and finance: Agendas for future research,” Financ. Res. Lett., vol. 35, pp. 1-5, 2020.

[22] K. Gavriilidis, V. Kallinterakis, and I. Tsalavoutas, "Investor mood, herding and the Ramadan effect," J. Econ. Behav. Organ., vol. 132, pp. 23-38, 2016.

[23] H. Y. Liu, "The Importance of Trust Distance on Stock Market Correlation: Evidence From Emerging Economics,” J. Borsa Istanbul Rev., vol. 20, pp. 37-47, 2020.

[24] E. M. Ferneini, “The Financial Impact of COVID-19 on our Practice,” J. Oral Maxillofac. Surg., 2020.

[25] T. Trimulato, “Analisis Potensi Produk Musyarakah Terhadap Pembiayaan Sektor Riil Umkm,” J. Ekon. Stud. Pembang., vol. 18, no. 1, pp. 41-51, 2017.

[26] R. S. R. Viverita, Arief W.Lubis, Yosman Bustaman, "Foreign Bank Entry and Credit Allocation to SMEs: Evidence from ASEAN Countries. Procedia," Soc. Behav. Sci., vol. 211, pp. 1049-1056, 2015.

[27] I. Ghozali, Aplikasi Analisis Multivariate Dengan Program SPSS. Semarang: Badan Penerbit Universitas Diponegoro,
2011.

[28] M. Shahulhameedu, "Financial Inclusion - Issues in Measurement and Analysis,” J. Curr. Res. Acad. Rev., vol. 2, no. 2, pp. 116-24, 2014.

[29] B. and Y. D. H. Saleh, "Penggunaan Teknologi Informasi Di Kalangan Pelaku Usaha Mikro Kecil Menengah Di Daerah Perbatasan (Studi Di Kabupaten Belu Provinsi Nusa Tenggara Timur) Use of Information Technology among Performers Micro Small Medium Enterprises in the Border Area S.”," 2016, vol. 1, no. 2, pp. 141-52.

[30] R. Kamath, "Financial Inclusion Vis-a-Vis Social Banking," Econ. Polit. Wkly., vol. 42, no. 15, pp. 1334-35, 207 AD.

[31] B. K. H. H. A. D. L. Dirk G., "Bitcoin: Medium of exchange or speculative assets?,” J. Int. Financ. Mark. Institutions Money, vol. 54, pp. 177-189, 2018.

[32] H. Z. Rini, "Peran Perbankan Syariah Terhadap Eksistensi UMKM Industri Rumah Tangga Batik Laweyan," Academia, vol. 1, no. 1, 2017.

[33] N. Nengsih, "Peran Perbankan Syariah Dalam Mengimplementasikan Keuangan Inklusif Di Indonesia," 2015, vol. 14, no. 2, pp. 221-40.

[34] S. Lim and H. C. Basnet, "International Migration, Workers' Remittances and Permanent Income Hypothesis," World Dev., vol. xx, 2017.

[35] X. Dong and S. Yoon, "What global economic factors drive emerging Asian stock market returns? Evidence from a dynamic model averaging approach,” Econ. Model., vol. 77, no. 1, pp. 204-215, 2018.

[36] R. R. G. S. M. M. Aloui, "Uncertainty and crude oil returns," Energy Econ., vol. 55, pp. 92-100, 2016.

[37] F. Al-Mudhaf, "The Islamic calendar effects: Evidence from twelve stock markets,” Int. Res. J. Financ. Econ., vol. 87, pp. 185-191, 2012. 